\title{
Partial pancreatic agenesis
}

INSERM

\section{Source}

INSERM. (1999). Orphanet: an online rare disease and orphan drug data base. Partial pancreatic agenesis. ORPHA:2805

Partial agenesis of the pancreas is characterized by the congenital absence of a critical mass of pancreatic tissue. 